Article

\title{
Cytotoxic and Membrane Cholesterol Effects of Ultraviolet Irradiation and Zinc Oxide Nanoparticles on Chinese Hamster Ovary Cells
}

\author{
Regina E. Kuebodeaux, Paul Bernazzani ${ }^{\circledR}$ and Thi Thuy Minh Nguyen * \\ Department of Chemistry and Biochemistry, Lamar University, Beaumont, TX 77710, USA; \\ rekuebodeaux@gmail.com (R.E.K.); paul.bernazzani@lamar.edu (P.B.) \\ * Correspondence: ttnguyen15@lamar.edu; Tel.: +1-409-880-7262
}

Received: 30 September 2018; Accepted: 13 November 2018; Published: 15 November 2018

\begin{abstract}
Zinc Oxide ( $\mathrm{ZnO})$ nanoparticles are suspected to produce toxic effects toward mammalian cells; however, discrepancies in the extent of this effect have been reported between different cell lines. Simultaneously, high levels of ultraviolet (UV-C) radiation can have carcinogenic effects. The mechanism of this effect is also not well understood. Due to similarities in phenotype morphology after cell exposure to $\mathrm{ZnO}$ nanoparticles and UV-C irradiation, we emit the hypothesis that the toxicity of both these factors is related to damage of cellular membranes and affect their sterol content. Wild-type Chinese Hamster Ovary (CHO-K1) cells were exposed to $\mathrm{ZnO}$ nanoparticles or UV-C radiation. The amount of absorbed $\mathrm{ZnO}$ was determined by UV-visible spectroscopy and the changes in sterol profiles were evaluated by gas chromatography. Cell viability after both treatments was determined by microscopy. Comparing morphology results suggested similarities in toxicology events induced by $\mathrm{ZnO}$ nanoparticles and UV exposure. UV-C exposure for $360 \mathrm{~min}$ disrupts the sterol metabolic pathway by increasing the concentration of cholesterol by 21.6 -fold. This increase in cholesterol production supports the hypothesis that UV irradiation has direct consequences in initiating sterol modifications in the cell membrane.
\end{abstract}

Keywords: UV-radiation; ZnO; toxicity; sterol content; cholesterol

\section{Introduction}

Advances in the field of nanotechnology where nanoparticles are commonly used in catalysts, sensors, and photovoltaic devices [1-3], as well as in the biomedical field for nanovaccines, nanodrugs, and diagnostic imaging tools [4-7], may also be associated with different health issues. The potential health impact nanoparticles raise concerns the fact that they have been incorporated into products used on a daily basis, as well as in medical products. There are several factors that determine nanoparticle cytotoxicity: the size, shape, surface charge, hydrophobicity, and heavy metal content [8]. It is important to understand what happens on a cellular level after nanoparticles have entered the human body through inhalation, ingestion, or absorption through the skin. Typically, the smaller the nanoparticle, the more cytotoxic it becomes due to its high surface area to volume ratio. Some studies revealed that not only can nanoparticles pass through cellular membranes, but they can also pass through the blood-brain barrier, which can result in organ deposition and interaction with biological systems and, therefore, alter the chemical biosynthesis [7,9-11].

Zinc Oxide $(\mathrm{ZnO})$ nanoparticles are widely used [12] and recent investigations discuss their cytotoxicity, in particular, the relation between $\mathrm{Zn}^{2+}$ cations and the generation of reactive oxidative species, which contribute significantly to the degenerescence of macromolecules and, therefore, to the toxicity of $\mathrm{Zn}^{2+}[13,14]$. In addition, the interaction of zinc in mammalian cells is complex. For example, 
zinc has been found to bind to enzymes related to sterol regulation [15] and help regulate the structure of cell membranes [16]. Hence, the possibility exists that $\mathrm{ZnO}$ nanoparticles will affect the sterol biosynthetic pathway, impacting the stability of the membrane and the phagocytosis process.

Another process that may affect sterol production in cells is the exposure to ultraviolet (UV) radiation. UV radiation is categorized into three wavelength ranges: long wave UV-A (315-400 nm), medium wave UV-B (280-315 nm), and short-wave UV-C (100-280 nm) [17-20]. The most energetic region, UV-C, is typically shielded by the ozone layer of the earth's atmosphere; however, due to ozone damage in recent years, the possibility exists that these radiations may reach the surface of the earth and affect sterol production in microalgae [21]. The effects of UV irradiation on mammalian cells remains unclear. In addition, UV radiation causes many harmful effects particularly regarding skin malignancies and severe damage to nucleic acids leading to DNA mutations; however, it can also be beneficial by creating vitamin D3 and is coupled in drug therapy applications for curing skin diseases like psoriasis and vitiligo [17,21]. The high energy radiation can cause damage to living organisms either by direct absorption through cellular chromophores or by indirect means through photo-sensitization mechanisms [21]. The indirect mechanism results in the formation of a reactive oxidative species, which can damage DNA, proteins, fatty acids, and saccharides [2]. There are therefore parallels between the effect of exposure to UV-C radiation and zinc ions. Both seem to affect the sterol biosynthetic pathways, and both can cause the generation of reactive oxidative species that lead to harmful effects.

We report the comparison of the cytotoxic effect of $\mathrm{ZnO}$ nanoparticles and UV-C irradiation on Chinese Hamster Ovary (CHO-K1) cells. We postulate that when exposed to either $\mathrm{ZnO}$ nanoparticles or UV radiation, the stability of cellular membranes will be modified because of variations in the sterol profile. Several analyses were performed on $\mathrm{CHO}$ cells after exposure to $\mathrm{ZnO}$ nanoparticles and UV-C irradiation to determine the amount of $\mathrm{ZnO}$ nanoparticles that cells can absorb, and alterations in cell growth and viability, DNA, and sterol profiles. The amount of $\mathrm{ZnO}$ nanoparticles was quantified using UV-Visible spectroscopy. Cell morphology and viability was determined with the use of compound light microscopy and the trypan blue exclusion method. Changes in DNA composition were visualized using agarose gel electrophoresis and sterol profile modifications were analyzed by gas chromatography.

\section{Results and Discussion}

\subsection{UV-Visible Spectroscopy after ZnO Treatment}

The $\mathrm{ZnO}$ nanoparticles used in this study were less than $100 \mathrm{~nm}$ in size. This is on the same scale as some biomolecules; therefore, we hypothesize that they are capable of passing through the protective cellular membrane. If so, nanoparticles could potentially enter the interior environment of the cell and this effect needs to be quantified.

UV-visible spectroscopy was used to determine the amount of $\mathrm{ZnO}$ that $\mathrm{CHO}-\mathrm{K} 1$ cells absorbed after $24 \mathrm{~h}$ of exposure, by first determining the wavelength corresponding to the maximum absorbance ( $\lambda$ max) of the $\mathrm{ZnO}$ nanoparticles dissolved in the F-12K medium. Figure 1 displays the UV-visible spectra of the controls used: Ham's F-12K and $0.1 \mathrm{mg} / \mathrm{mL} \mathrm{ZnO}$ in the F-12K medium. Nanoparticles tend to scatter the light when they are analyzed by UV-Visible spectroscopy, which shifted the baseline upward. The baseline shift was taken into account when determining the absorbance at $\lambda \max$. The $\lambda \max$ of the $0.1 \mathrm{mg} / \mathrm{mL} \mathrm{ZnO}$ solution was determined to be at $372 \mathrm{~nm}$. The absorbance at the wavelength was calculated by subtracting the absorbance at $390 \mathrm{~nm}$ from the absorbance at the highest peak. Ham's F-12K was also analyzed and its $\lambda$ max was found to be around $550 \mathrm{~nm}$. 


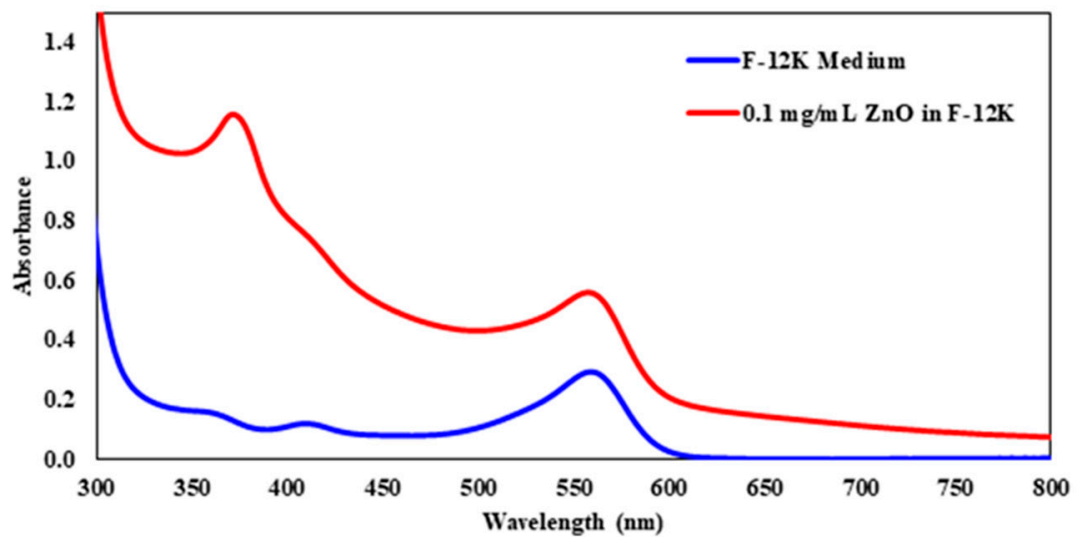

Figure 1. The UV-Visible Spectra of the controls: Ham's F-12K medium and $0.1 \mathrm{mg} / \mathrm{mL}$ of ZnO solution in an F-12K medium.

After establishing the $\lambda$ max from the control sample, each $\mathrm{ZnO}$ exposed sample was analyzed by UV-Vis spectroscopy. This was performed to understand how the $\mathrm{CHO}$ cells respond to different $\mathrm{ZnO}$ concentration doses, and to determine at what concentration the cells reach saturation. Once the $\mathrm{ZnO}$ treatment was complete, the cells were pelleted by centrifugation and the clear supernatant liquid was analyzed to determine the number of unabsorbed $\mathrm{ZnO}$ nanoparticles. The UV-visible spectra after this first wash can be seen in Figure 2. The figure displays the unabsorbed $\mathrm{ZnO}$ absorbances from the wavelength range of $300-800 \mathrm{~nm}$. From the lower concentrations $(0-100 \mu \mathrm{g} / \mathrm{mL})$, it is challenging to see a difference with the addition of $\mathrm{ZnO}$. However, at 250 and $500 \mu \mathrm{g} / \mathrm{mL}$, an absorbance at $372 \mathrm{~nm}$ can be observed clearly.

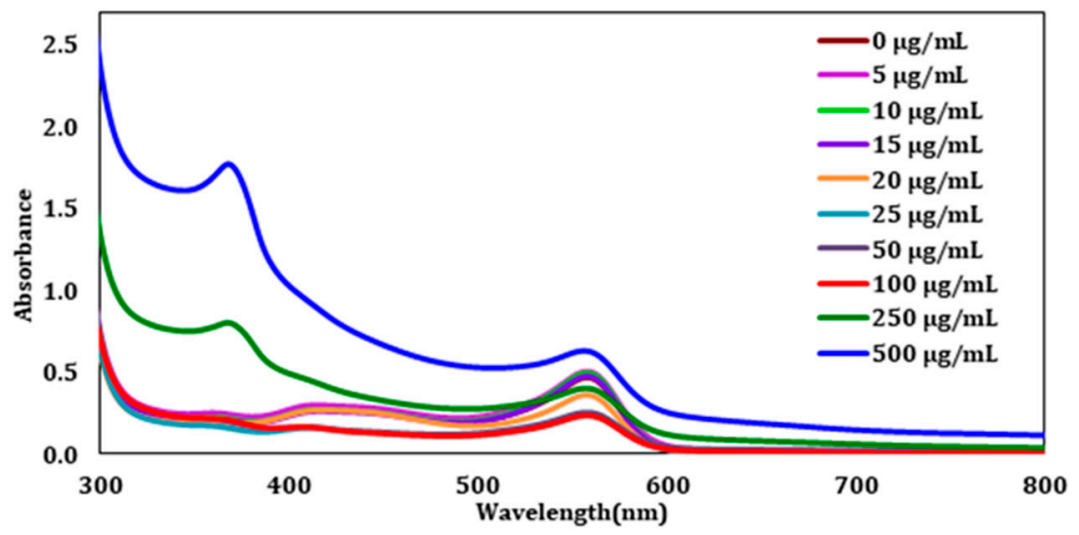

Figure 2. The UV-Visible Spectra of the supernatant of wash 1 after treatment with different $\mathrm{ZnO}$ concentrations.

The absorbance at $372 \mathrm{~nm}$ was used to determine the concentration of $\mathrm{ZnO}$ that $\mathrm{CHO}-\mathrm{K} 1$ cells absorbed for each of the samples with the help of Equation (1).

$$
C_{s}=C_{\text {Initial }[\mathrm{ZnO}]}-\left[\frac{\left(C_{\mathcal{c}} \times A_{s}\right)}{A_{c}}\right]
$$

where $C_{s}$ is the concentration of the sample and $A_{s}$ is the absorbance at $372 \mathrm{~nm}$ for the sample. $C_{c}$ and $A_{c}$ correspond to the concentration and absorbance at $372 \mathrm{~nm}$ for the $\mathrm{ZnO}$ control. $C_{\text {Initial [ }[\mathrm{ZnO}]}$ is the starting concentration of $\mathrm{ZnO}$ that each sample received. The concentration of each sample was calculated in $\mathrm{mM}$ and was plotted against the concentration of $\mathrm{ZnO}$ that was initially added to $\mathrm{CHO}$ cells (Figure 3). A steady increase in the amount of absorbed $\mathrm{ZnO}$ with an increase in dosage was observed. As expected, the absorption reaches a plateau when large concentrations of $\mathrm{ZnO}$ are present, 
indicating the possibility that the at least $250 \mu \mathrm{g} / \mathrm{mL} \mathrm{ZnO}$ cause CHO-K1 cells to become saturated and no longer absorb or uptake the nanoparticles. The maximum amount these mammalian cells absorbed was $2.2 \pm 0.2 \mathrm{mM} \mathrm{ZnO}$. The $250 \mu \mathrm{g} / \mathrm{mL}$ sample had an initial concentration of $3.1 \mathrm{mM}$; therefore, around $70 \%$ of the $\mathrm{ZnO}$ nanoparticles were absorbed by the cells at this concentration. For the $500 \mu \mathrm{g} / \mathrm{mL}$ sample, $6.2 \mathrm{mM}$ was the starting concentration of $\mathrm{ZnO}$, which corresponds to around $35 \%$ absorption.

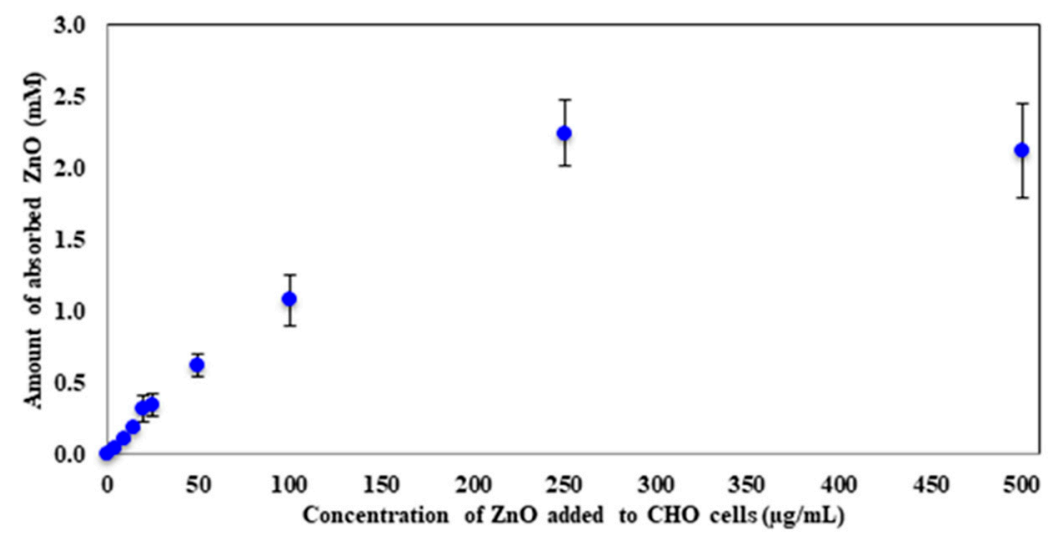

Figure 3. The average amount of absorbed $\mathrm{ZnO}(\mathrm{mM})$ after $24 \mathrm{~h}$ of $\mathrm{ZnO}$ treatment. Error bars represent the standard deviation of triplicates.

The results indicate that $\mathrm{CHO}-\mathrm{K} 1$ cells are indeed capable of absorbing $\mathrm{ZnO}$ nanoparticles after $24 \mathrm{~h}$ of exposure. The amount absorbed by the cell increased with increasing $\mathrm{ZnO}$ dose and a saturation parameter was established at $250 \mu \mathrm{g} / \mathrm{mL}$. To determine the toxicity of these nanoparticles, cell morphological changes and viability were examined by microscopy.

\subsection{Cell Viability and Morphology}

Cell viability and cell morphology help establish the degree of toxicity of external agents such as the addition of $\mathrm{ZnO}$ nanoparticles or UV-C irradiation. CHO-K1 cell viability and morphology were determined using a BioExpress GeneMate inverted microscope and trypan blue exclusion test. Trypan blue is a staining technique that allows for the observer to differentiate which cells are no longer viable. The unhealthy/dead cells have damaged cell membranes. This allows the cell to absorb the trypan blue dye and become blue, while the healthy, viable cells are not stained. Once the viable cells can be identified, the percent viability and viable cell concentration (viable cells $/ \mathrm{mL}$ ) can be calculated using a hemocytometer and Equations (2) and (3).

$$
\begin{gathered}
\% \text { Viability }=[1-(\text { Number of blue cells } \div \text { Number of total cells })] \times 100 \\
\text { Viable cells } / \mathrm{mL}=\text { Average number of viable cells } \times 16 \times 104
\end{gathered}
$$

CHO-K1 cells are adherent epithelial cells, meaning that when the cell culture matures, the cells attach to the culture flask. After the cells have adhered to the culture flask, their morphology changes to become more stretched and oblong, whereas the younger cells that have not adhered have a circular morphology. Figure 4 displays micrographs of these two different growth stages that $\mathrm{CHO}-\mathrm{K} 1$ cells exhibit: the initial suspension stage (panel A) and the mature adherent stage (panels B and C). While cells in the suspension stage have a rounded morphology, mature cells in the adherent stage show significant elongation. The rounded cells still observed in panels B and C are expected and represent newly formed immature cells. 


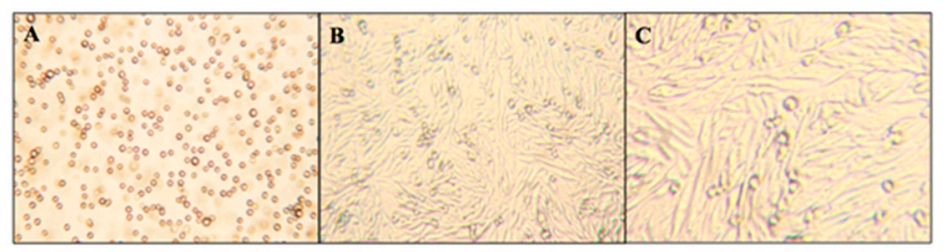

Figure 4. The wild-type $\mathrm{CHO}$ cell micrographs of the Initial Suspension Stage at $250 \times(\mathbf{A})$ and the Mature Adhered Phase at $250 \times($ B $)$ and at $400 \times(C)$.

\subsection{Cell Viability and Morphology after ZnO Treatment}

Figure 5 shows the percent viability curve from $0-500 \mu \mathrm{g} / \mathrm{mL} \mathrm{ZnO}$ after cell incubation in the presence of different amounts of nanoparticle for $24 \mathrm{~h}$ at $37^{\circ} \mathrm{C}$ with $5 \% \mathrm{CO}_{2}$. The cells were grown in the presence of $\mathrm{ZnO}$ in a complete growth medium containing Ham's F-12K media with $10 \%$ FBS and antibiotics. Cell viability after $\mathrm{ZnO}$ exposure was characterized with a decrease in the percent viability as the concentration of $\mathrm{ZnO}$ increased. From the concentrations of $15 \mu \mathrm{g} / \mathrm{mL}$ and lower, there was not much influence on viability. At $15 \mu \mathrm{g} / \mathrm{mL} \mathrm{ZnO,} \mathrm{91.6 \%} \mathrm{of} \mathrm{the} \mathrm{cells} \mathrm{were} \mathrm{still} \mathrm{viable.} \mathrm{As} \mathrm{the} \mathrm{amount} \mathrm{is}$ increased to $20 \mu \mathrm{g} / \mathrm{mL} \mathrm{ZnO}$, it fell to $80.3 \%$. A drastic drop of almost $24 \%$ in viability was observed between the $\mathrm{ZnO}$ concentrations of 20 to $25 \mu \mathrm{g} / \mathrm{mL}$. A similar decrease in percentage was found from 25 to $50 \mu \mathrm{g} / \mathrm{mL} \mathrm{ZnO}$. Higher amounts resulted in a gradual decline in viability and, eventually, the lowest viability of $11.0 \%$ was observed at the highest concentration of $500 \mu \mathrm{g} / \mathrm{mL} \mathrm{ZnO}$.

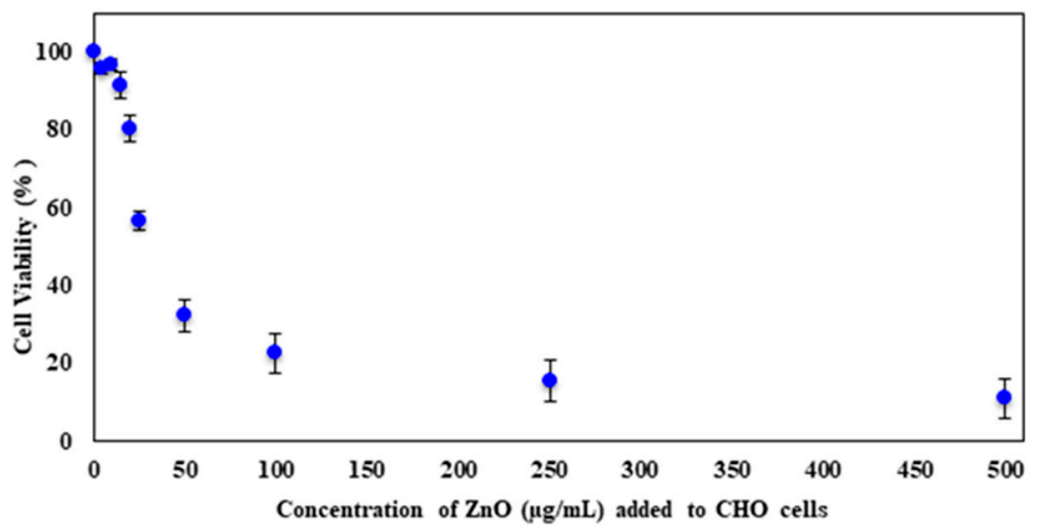

Figure 5. The average percent cell viability after $24 \mathrm{~h}$ of incubation with $\mathrm{ZnO}$. Error bars represent the standard deviation of triplicates.

As expected, viability analysis confirmed that $\mathrm{ZnO}$ nanoparticles are toxic to $\mathrm{CHO}-\mathrm{K} 1$ cells at higher concentrations, but morphology changes provide additional information about the toxicity of these nanoparticles. Changes in morphology could mean that the natural behavior of the cell is altered. Figure 6 shows the microscopy images of the culture flasks using an inverted microscope. The different panels represent typical behavior under different $\mathrm{ZnO}$ amounts. Images indicate that the morphology of $\mathrm{CHO}-\mathrm{K} 1$ cells was directly impacted as the concentration of $\mathrm{ZnO}$ present increased. At concentrations of $20 \mu \mathrm{g} / \mathrm{mL} \mathrm{ZnO}$ and below, the cells were able to maintain their natural adherent behavior. At $25 \mu \mathrm{g} / \mathrm{mL}$ of $\mathrm{ZnO}$, some $\mathrm{CHO}$ cells were able to maintain the adherent morphology, but the majority of the cell culture expressed a round physiology. However, at amounts exceeding $25 \mu \mathrm{g} / \mathrm{mL} \mathrm{ZnO}$, the CHO-K1 cells stayed in the media and grew similar to suspension cells and stayed circular in form. 


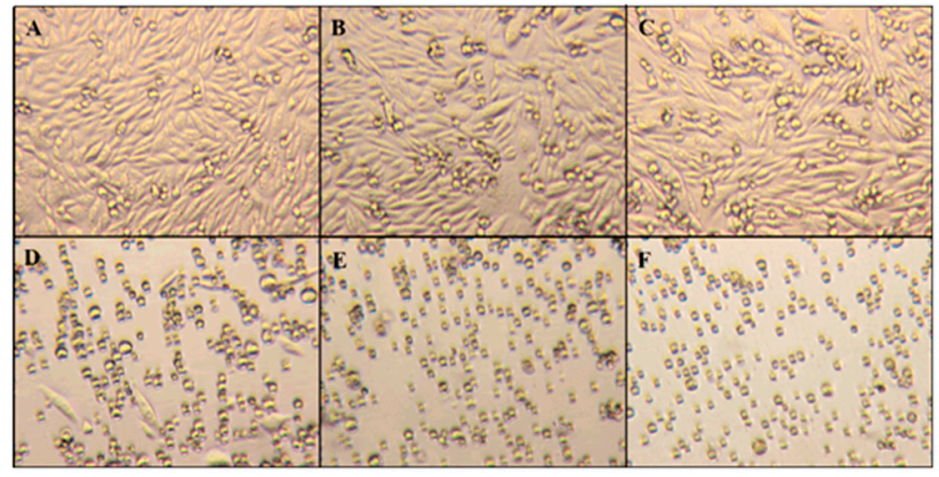

Figure 6. The $\mathrm{CHO}$ cell morphology micrographs $(400 \times)$ of $0 \mu \mathrm{g} / \mathrm{mL}$ control $(\mathbf{A}), 10 \mu \mathrm{g} / \mathrm{mL}(\mathbf{B})$, $15 \mu \mathrm{g} / \mathrm{mL}$ (C), $25 \mu \mathrm{g} / \mathrm{mL}$ (D), $50 \mu \mathrm{g} / \mathrm{mL}$ (E), and $100 \mu \mathrm{g} / \mathrm{mL} \mathrm{ZnO} \mathrm{(F)} \mathrm{after} 24 \mathrm{~h}$ of exposure.

The presence of Zinc oxide nanoparticles not only impacts the viability of $\mathrm{CHO}$ cells, but also influences their physical characteristics. When $25 \mu \mathrm{g} / \mathrm{mL}$ of $\mathrm{ZnO}$ and above were introduced, the cells were no longer able to completely adhere to the culture flask. This indicates that the mode of toxicity caused the natural function of the cell to change. These results were compared with the viability and morphological deviations after UV-C exposure.

\subsection{Cell Viability and Morphology after UV-C Exposure}

Figure 7 shows the viability curve of $\mathrm{CHO}$ cells as they were exposed to UV-C for longer times. With the increase in UV exposure time, there was a decrease in cell viability. The result provides for an almost linear relation, rather than an exponential decrease as the $\mathrm{ZnO}$ treatment provided. On average, cell viability dropped by $12.1 \% / \mathrm{min}$ during the span of $360 \mathrm{~min}$ of UV exposure. At the maximum UV exposure time of $360 \mathrm{~min}$, the number of viable cells was $27.0 \%$.

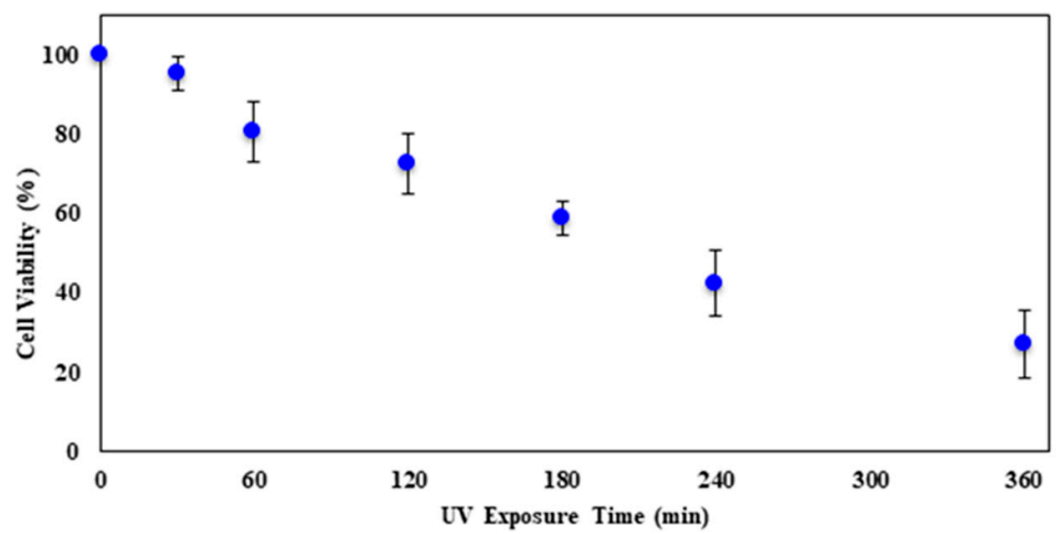

Figure 7. The average percent cell viability after different UV-C exposure times. Error bars represent the standard deviation of triplicates.

To determine the effect of UV-C irradiation on cell morphology, Figure 8 displays micrographs taken directly from the petri dish after UV exposure times of 0,60, 180, and $360 \mathrm{~min}$. All exposure times resulted in suspension-like cell cultures with the cellular structure staying in circular form. UV-C irradiation showed a similar, although stronger, impact on $\mathrm{CHO}$ cell morphology compared to exposure to $\mathrm{ZnO}$ nanoparticles. These results indicate that UV-C exposure has an extreme impact on cell morphology, but do not reveal how this radiation affects the cell membrane. As previously discussed, because the phenotype shows that cell membranes are affected, the toxicity can be attributed to either the formation of reactive oxidative species or an effect on the sterol biosynthetic pathway, which directly 
impacts the membrane. This latter assumption can be evaluated through gas chromatography analysis of the extracted membrane sterols after each UV exposure time.

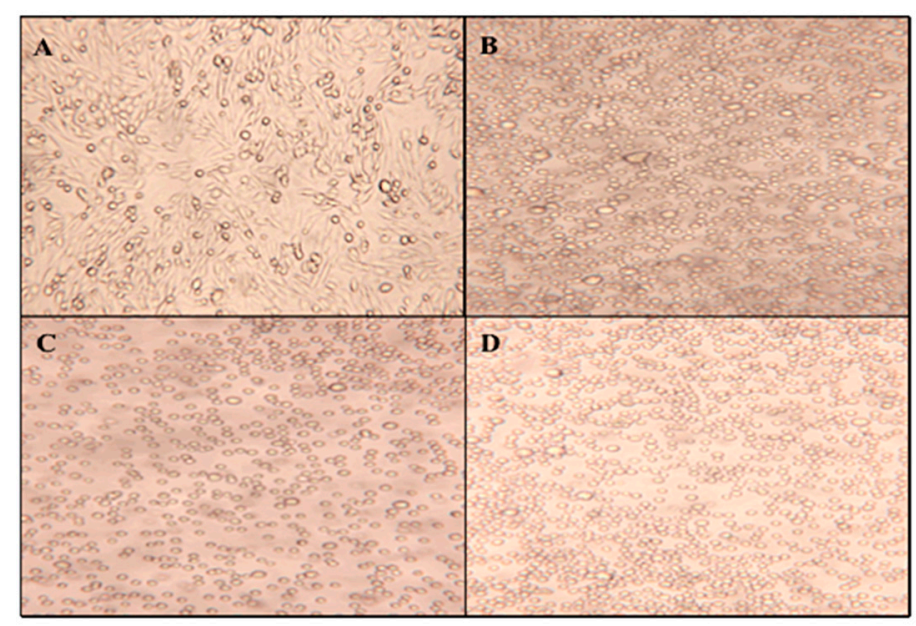

Figure 8. The CHO cell morphology micrographs (250×) of Wild-type CHO-K1 (A), $60 \mathrm{~min}$ (B), $180 \mathrm{~min}$ (C), and $360 \mathrm{~min}$ (D) of UV exposure.

Evaluation of the possible damage caused by reactive oxidative species on DNA can also be determined. Alterations in the DNA were first assessed before analyzing the sterol profile.

\subsection{Agarose Gel Electrophoresis after ZnO Treatment}

Agarose gel electrophoresis was used to evaluate possible alterations in CHO-K1 genomic DNA after incubation of different concentrations of $\mathrm{ZnO}$. Electrophoresis was performed on whole genomic DNA without the use of restriction enzymes. Since restriction enzymes were not used, distinct bands were not observed in the agarose gel. Figure 9 displays the electrophoresis gel following this experiment.

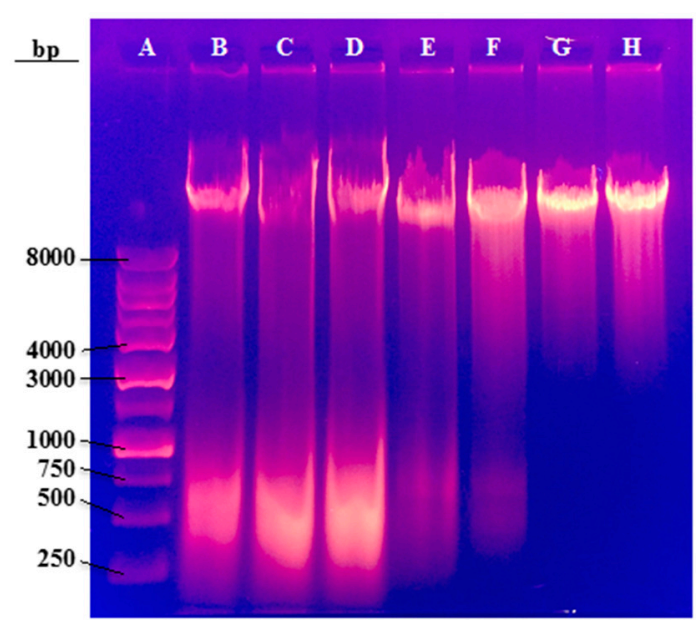

Figure 9. A total of $1 \%$ of Agarose gel of the samples exposed to different concentrations of ZnO: DNA Ladder (A), $0 \mu \mathrm{g} / \mathrm{mL}$ (B), $5 \mu \mathrm{g} / \mathrm{mL}$ (C), $10 \mu \mathrm{g} / \mathrm{mL}$ (D), $15 \mu \mathrm{g} / \mathrm{mL}$ (E), $25 \mu \mathrm{g} / \mathrm{mL}$ (F), $50 \mu \mathrm{g} / \mathrm{mL}$ (G), and $100 \mu \mathrm{g} / \mathrm{mL}(\mathbf{H})$.

The samples of 0 to $15 \mu \mathrm{g} / \mathrm{mL} \mathrm{ZnO}$ (Lanes B-D) have a prominent band smear towards low molecular weight around 500 base pairs. This band corresponds to RNA molecules that were also purified during DNA extraction. Lanes $\mathrm{E}$ and $\mathrm{F}(20$ and $25 \mu \mathrm{g} / \mathrm{mL} \mathrm{ZnO}$ ) displayed the bands as well, but were in trace amounts that resulted in faint bands. The higher concentrations of 50 and 
$100 \mu \mathrm{g} / \mathrm{mL}$ of $\mathrm{ZnO}$ (lanes $\mathrm{G}$ and $\mathrm{H}$ ) had no appearance of the RNA band. This indicates that with increased $\mathrm{ZnO}$ dosage, CHO-K1 cell's RNA is destroyed. If RNA is no longer synthesized within the cell, then DNA replication cannot occur as well. When DNA replication is halted, the cell can no longer produce the necessary proteins for maintenance, survival, and the creation of a healthy internal environment. This explains why $\mathrm{ZnO}$ has such a direct effect on cell viability and morphology at the higher concentration doses.

Termination of cell replication is an extreme consequence of toxicity brought on by $\mathrm{ZnO}$ nanoparticles; therefore, membrane sterol modifications were not investigated. However, since the UV exposed $\mathrm{CHO}$ samples did not present this effect, modifications in their sterol profile was explored.

\subsection{Gas Chromatography after UV Exposure}

We emit the hypothesis that exposure to UV-C results in a direct effect on cell membrane integrity. Gas chromatography was utilized to analyze the sterol profile of $\mathrm{CHO}-\mathrm{K} 1$ cells after UV-C exposure. Cholesterol was used as a standard at a concentration of $1.0 \mathrm{mg} / \mathrm{mL}$. This specific sterol was chosen as a standard because cholesterol is the most abundant sterol found within mammalian cellular membranes. Figure 10 represents the typical GC trace of the cholesterol standard. The prominent peak at around $21 \mathrm{~min}$ corresponds to pure cholesterol, while the smaller peaks at around 25 and 26 min represent derivatives.

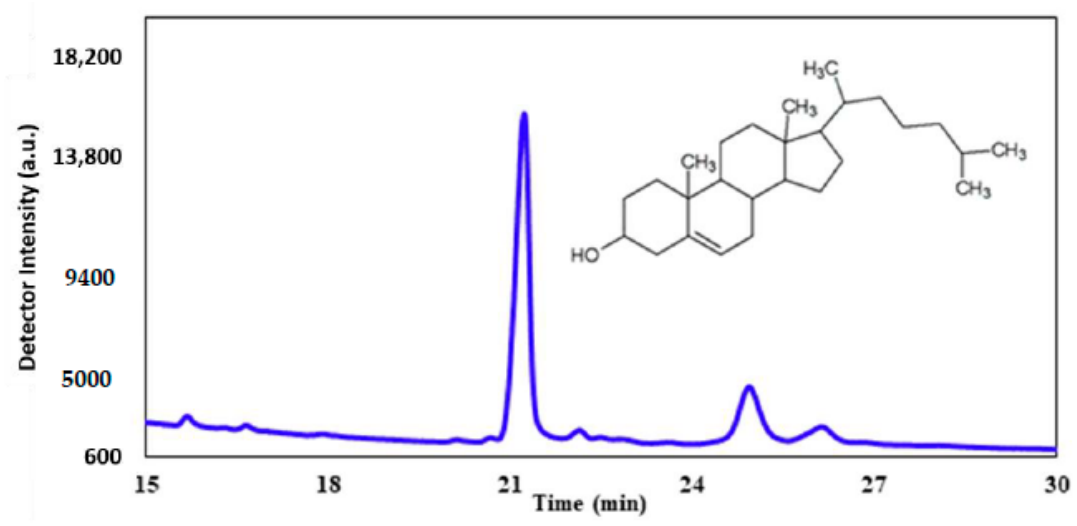

Figure 10. The GC chromatogram of standard cholesterol $(1.0 \mathrm{mg} / \mathrm{mL})$.

The sterol profiles after $0,60,240$, and $360 \mathrm{~min}$ of UV-C exposure showed interesting results related to the deviation of cholesterol content. The GC chromatograms in Figure 11 show the peak related to cholesterol at a retention time of about $21 \mathrm{~min}$, but do not take into account the number of cells that are viable in each sample. A decrease was observed in the amount of cholesterol after $60 \mathrm{~min}$ of UV exposure when compared to the sample that was not exposed. However, after $240 \mathrm{~min}$ of exposure, there was a slight increase in the amount of cholesterol that would generally be present under normal conditions. Intriguingly, after $360 \mathrm{~min}$ of exposure, the amount of cholesterol was substantially greater compared to all other samples. This provides evidence that UV-C irradiation has a direct impact on cholesterol found within the cell membrane of $\mathrm{CHO}-\mathrm{K} 1$ cells, particularly after longer exposures.

Direct evaluation of the GC peak area does not demonstrate the true impact of cholesterol modification after UV exposure because each sample had a different concentration of cells that were left viable. Table 1 displays the calculated concentrations of cholesterol before and after the viability percentage was taken into account.

Figure 12 displays the calculated corrected concentration of cholesterol in $\mu \mathrm{M}$ based on the viability of each exposure time. An increase in the amount of cholesterol with increasing exposure time was found when correcting for concentration based on the number of viable cells after each exposure. These results support the hypothesis that UV-C irradiation affects cell membrane cholesterol levels. 


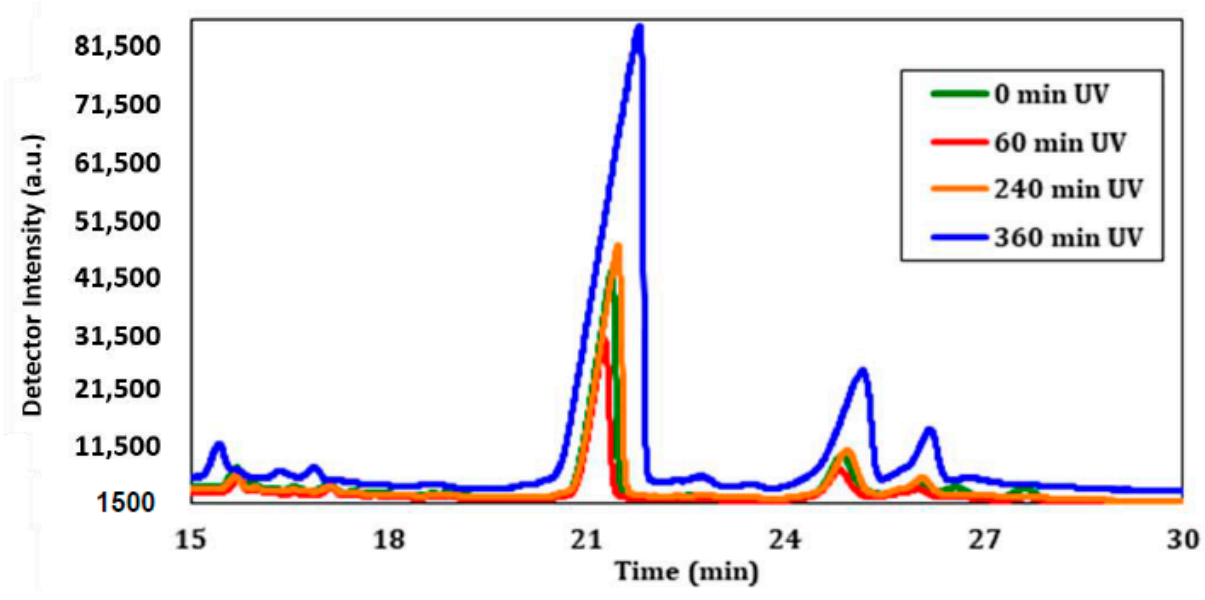

Figure 11. The GC chromatograms after $\mathrm{CHO}$ UV exposure for 0, 60, 240, and $360 \mathrm{~min}$.

Table 1. The GC chromatogram areas, concentration $(\mu \mathrm{g} / \mu \mathrm{L}$ and $\mu \mathrm{M})$, percent viability, and calculated corrected cholesterol concentration $(\mu \mathrm{g} / \mu \mathrm{L}$ and $\mu \mathrm{M})$ based on cell viability after UV exposure starting with $1 \times 10^{7}$ cells per sample ${ }^{\text {a }}$.

\begin{tabular}{|c|c|c|c|c|c|c|}
\hline $\begin{array}{l}\text { UV Exposure } \\
\text { Sample (min) }\end{array}$ & $\begin{array}{l}\text { Area }\left(10^{5}\right) \\
\quad \text { (a.u.) }\end{array}$ & $\begin{array}{c}\text { Calc. } \\
(\mu \mathrm{g} / \mu \mathrm{L})\end{array}$ & $\begin{array}{l}\text { Calc. } \mu \mathrm{M} \\
\left(10^{-2}\right)\end{array}$ & $\begin{array}{c}\text { Viability } \\
\text { (\%) }\end{array}$ & $\begin{array}{c}\text { Corrected } \\
(\mu g / \mu L)\end{array}$ & $\begin{array}{l}\text { Corrected } \\
\mu \mathrm{M}\left(10^{-2}\right)\end{array}$ \\
\hline Standard & 2.34 & 1.00 & 1.00 & - & - & - \\
\hline 0 & 8.76 & 3.74 & 0.97 & 100.0 & 3.74 & 0.97 \\
\hline 60 & 6.48 & 2.77 & 0.72 & 78.1 & 3.55 & 0.92 \\
\hline 240 & 12.37 & 5.29 & 1.37 & 36.3 & 14.58 & 3.77 \\
\hline 360 & 37.79 & 16.17 & 4.18 & 20.0 & 80.83 & 20.90 \\
\hline
\end{tabular}

${ }^{\text {a }} \mathrm{UV}$ exposure sterol samples were dissolved in $20 \mu \mathrm{L}$ of methanol prior to GC injection.

The fact that viability and cholesterol are inversely proportional implies that the increase in cholesterol undermines the integrity of the cellular membrane, which results in the change in morphology and apoptosis. DNA and protein analyses need to be performed in future studies to better understand the mechanism that stimulates the spike in cholesterol production upon UV-C exposure.

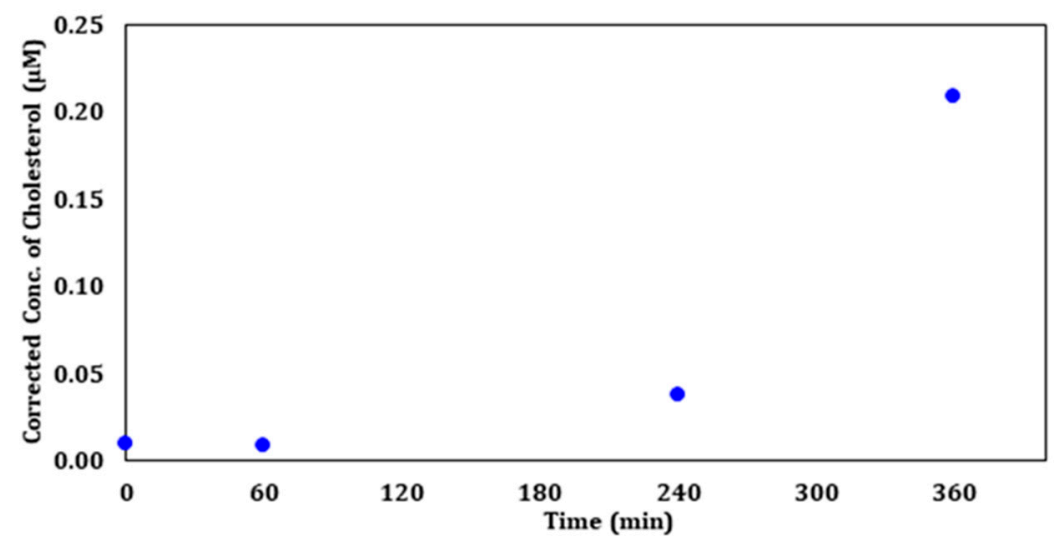

Figure 12. The corrected concentration of cholesterol $(\mu \mathrm{M})$ after UV Exposure for 0, 60, 240, and $360 \mathrm{~min}$.

\section{Materials and Methods}

\subsection{Cell Culture}

Wild-type Chinese Hamster Ovary, CCL-61, (CHO-K1) purchased from American Type Culture Collection (ATCC, Manassas, VA, USA), were cultured in Ham's F-12K with L-Glutamine medium (ATCC, 30-2004) containing 10\% fetal bovine serum (FBS) (ATCC, 30-2020) and 1\% 
Penicillin/Streptomycin (ATCC, 30-2300). All culture media, serum, and antibiotics were purchased from ATCC. The cells were cultured at $37^{\circ} \mathrm{C}$ in an atmosphere containing $5 \%$ carbon dioxide $\left(\mathrm{CO}_{2}\right)$ in a Steri-Cycle $\mathrm{CO}_{2}$ Incubator (Thermo Scientific, Waltham, MA, USA, Model 370 Series). The cultures were grown in T-25 culture flasks until $80-90 \%$ confluency before $\mathrm{ZnO}$ (Sigma Aldrich, St-Louis, MO, USA, number 721077) or UV-C exposure.

\subsection{Cryopreservation of $\mathrm{CHO}-\mathrm{K} 1$ Cells}

Cell culture was grown until $90 \%$ confluency and checked for cell viability and contamination immediately before cryopreservation. For CHO-K1 cells, the cryopreservation medium was prepared with Ham's F-12K with 20\% FBS supplemented with 5\% DMSO (ATCC) and 1\% Penicillin/Streptomycin. Care was given to not add undiluted DMSO to the cell suspension as the dissolution of DMSO in aqueous solutions gives off heat.

The cells were collected by gentle centrifugation with a Thermo Scientific Sorvall Legend X1R centrifuge at $2500 \mathrm{rpm}$ for $10 \mathrm{~min}$, followed by the suspension of the pellet with the cryopreservation medium at a concentration of $1 \times 10^{6}$ to $5 \times 10^{6}$ viable cells $/ \mathrm{mL}$. The cryopreservation vials were labeled and $1 \mathrm{~mL}$ of the cell suspension was added to each vial and then sealed. The cells were allowed to equilibrate in the freeze medium at room temperature for a minimum of $15 \mathrm{~min}$, but no longer than 40 . This time was usually taken up in dispensing aliquots of the cell suspension into the vials. If left for longer than $40 \mathrm{~min}$ at room temperature, the cell viability may decline due to the DMSO. The vials were then placed on ice and stored in an $-80{ }^{\circ} \mathrm{C}$ freezer for at least $24 \mathrm{~h}$. Then the vials were transferred quickly to an ABS1 CryoMax Liquid Nitrogen Dewar (American BioTech Supply, Phenix Research Products, Candler, NC, USA) for long-term storage in the liquid nitrogen vapor phase. The location of vials within the Dewar was then recorded for future reference.

\subsection{Subculturing CHO-K1 Cells}

CHO-K1 cells were sub-cultured after they were $90 \%$ confluent in a T-25 flask. The culture medium was removed and discarded. Then the cell layer was rinsed with Ham's F-12K without serum several times and discarded. This was done to remove all traces of the serum, which contains the trypsin inhibitor. After rinsing, $2 \mathrm{~mL}$ of $0.25 \%(w / v)$ Trypsin- $0.53 \mathrm{mM}$ EDTA solution (ATCC) was added to each flask. Trypsin is an enzyme that allows the adherent cells to detach from the culture flask. To facilitate dispersal, the cells were placed at $37^{\circ} \mathrm{C}$ and took about $10-15 \mathrm{~min}$ to complete. The cells should be monitored under an inverted microscope until the cell layer is dispersed in the solution. After the cells had completely detached from the flask, F-12K media without serum was added and the cells were aspirated by gently pipetting. Cell count and viability were determined, followed by centrifugation at $2500 \mathrm{rpm}$ for $5 \mathrm{~min}$. The F-12K media was discarded and fresh media was added and the centrifugation process was repeated. Then complete growth medium of F-12 K supplemented with $10 \%$ FBS with $1 \%$ Penicillin/Streptomycin was added to the cell pellet and appropriate aliquots of the cell suspension were added to new T-25 culture vessels. The cultures were then incubated at $37^{\circ} \mathrm{C}$ and were examined the following days to ensure cell reattachment and active growth.

\section{4. $\mathrm{ZnO}$ Nanoparticle Treatment and Analysis}

CHO-K1 cells were exposed to 0, 5, 10, 15, 20, 25, 50, 100, 250, and $500 \mu \mathrm{g} / \mathrm{mL} \mathrm{ZnO}$ for $24 \mathrm{~h}$ at $37{ }^{\circ} \mathrm{C}$ with $5 \% \mathrm{CO}_{2}$ in either 12 well-culture plates or T-25 culture vessels. The dose selection was obtained experimentally. Systematic trials over a large range of dosage showed a range where cells were still viable. Sigma Aldrich (Sigma Aldrich, St-Louis, MO, USA) provided ZnO nanoparticles that were less than $100 \mathrm{~nm}$ in size. Prior to $\mathrm{ZnO}$ incubation, the cells were cultured until $90 \%$ confluency and then were sub-cultured and split into additional flasks and grown until they were $90 \%$ confluent. Tables 2 and 3 provides the specific volumes and concentrations used for the $24 \mathrm{~h} \mathrm{ZnO}$ treatment when a 12-well plate or a T-25 flask was used, respectively. 
A Thermo Scientific Evolution 260 Bio UV-Visible Spectrophotometer was utilized to determine the concentration of $\mathrm{ZnO}$ nanoparticles that were unabsorbed after treatment. This was done by measuring the absorbance of three supernatants from 200-800 nm of each sample. After ZnO treatment, the cells were centrifuged at $2500 \mathrm{rpm}$ for $5 \mathrm{~min}$ and the supernatant after centrifugation was analyzed by UV-Vis spectroscopy and classified as wash 1. Then PBS was added to the pelleted cells, resuspended, and centrifuged. This supernatant was analyzed and termed wash 2 . The process was repeated one more time with PBS to yield the final wash 3 . The controls used were $1 \mathrm{mg} / \mathrm{mL}$ and $0.1 \mathrm{mg} / \mathrm{mL} \mathrm{ZnO}$ in F-12K media with $10 \%$ FBS, PBS, and F-12K media with $10 \%$ FBS. Water was used as a blank to calibrate the spectrophotometer.

Table 2. The concentration and volumes of $\mathrm{ZnO}$ and the culture medium used for $\mathrm{ZnO}$ treatment in a 12-well plate ${ }^{\text {a }}$.

\begin{tabular}{|c|c|c|c|c|c|c|}
\hline Flask & {$[\mathrm{ZnO}](\mu \mathrm{g} / \mathrm{mL})$} & $\begin{array}{c}{[\mathrm{ZnO}]} \\
(\mu \mathrm{M})\end{array}$ & $\begin{array}{c}\text { Cell + } \\
\text { Media }(\mu L)\end{array}$ & $\begin{array}{c}\mathrm{ZnO}+\text { Media } \\
(1 \mathrm{mg} / \mathrm{mL})(\mu \mathrm{L})\end{array}$ & $\begin{array}{l}\text { Media } \\
(\mathrm{mL})\end{array}$ & $\begin{array}{l}\text { Total } \\
(\mathrm{mL})\end{array}$ \\
\hline 1 & 0 & 0.0 & 650 & 0 & 4.350 & 5 \\
\hline 2 & 5 & 61.5 & 650 & 25 & 4.325 & 5 \\
\hline 3 & 10 & 123.0 & 650 & 50 & 4.300 & 5 \\
\hline 4 & 15 & 184.5 & 650 & 75 & 4.275 & 5 \\
\hline 5 & 25 & 307.5 & 650 & 125 & 4.225 & 5 \\
\hline 6 & 50 & 615.0 & 650 & 250 & 4.100 & 5 \\
\hline 7 & 100 & 1230.0 & 650 & 500 & 3.850 & 5 \\
\hline
\end{tabular}

${ }^{\mathrm{a}} \mathrm{CHO}$ cells were seeded at $5 \times 10^{6}$ cells/well.

Table 3. The concentration and volumes of $\mathrm{ZnO}$ and the culture medium used for $\mathrm{ZnO}$ treatment in a T-25 culture flask ${ }^{\mathrm{a}}$.

\begin{tabular}{ccccccc}
\hline Sample & {$[\mathrm{ZnO}](\mu \mathrm{g} / \mathbf{m L})$} & $\begin{array}{c}{[\mathbf{Z n O}]} \\
(\boldsymbol{\mu M})\end{array}$ & $\begin{array}{c}\text { Cell }+ \\
\text { Media }(\mu \mathrm{L})\end{array}$ & $\begin{array}{c}\mathbf{Z n O}+\text { Media }(\mathbf{0 . 1} \\
\mathbf{m g} / \mathbf{m L})(\mu \mathrm{L})\end{array}$ & $\begin{array}{c}\text { Media } \\
(\mu \mathrm{L})\end{array}$ & $\begin{array}{c}\text { Total } \\
(\mu \mathrm{L})\end{array}$ \\
\hline 1 & 0 & 0.0 & 100 & 0 & 900 & 1000 \\
2 & 5 & 61.5 & 100 & 50 & 850 & 1000 \\
3 & 10 & 123.0 & 100 & 100 & 800 & 1000 \\
4 & 15 & 184.5 & 100 & 150 & 750 & 1000 \\
5 & 20 & 246.0 & 100 & 200 & 700 & 1000 \\
6 & 25 & 307.5 & 100 & 250 & 650 & 1000 \\
7 & 50 & 615.0 & 100 & 500 & 400 & 1000 \\
8 & 100 & 1230.0 & 100 & $100^{*}$ & 800 & 1000 \\
9 & 250 & 3075.0 & 100 & $250^{*}$ & 650 & 1000 \\
10 & 500 & 6150.0 & 100 & $500^{*}$ & 400 & 1000 \\
\hline
\end{tabular}

${ }^{\text {a }} \mathrm{CHO}$ cells were seeded at $5 \times 10^{6}$ cells/flask. ${ }^{*}$ Taken directly from $1.0 \mathrm{mg} / \mathrm{mL}$ stock of $\mathrm{ZnO} /$ Ethanol.

\subsection{DNA Purification and Agarose Gel Electrophoresis}

Chinese Hamster Ovary cell DNA was extracted and purified after $\mathrm{ZnO}$ treatment for $24 \mathrm{~h}$ at $37^{\circ} \mathrm{C}$ with PureLink Genomic DNA Mini Kit provided by Invitrogen. The procedure of preparing cell lysates, purifying, and extracting DNA was performed as the kit described for mammalian cells.

Agarose cell electrophoresis was performed with 1\% agarose gel, $1 \times$ Tris/Acetic Acid/EDTA (TAE) buffer (Bio-Rad, Hercules, Berkeley, CA, USA), and ethidium bromide in a Bio-Rad Mini-Sub Cell GT apparatus. A PowerPac basic power supply from Bio-Rad was used to provide the voltage current during electrophoresis. The DNA samples were prepared with $6 \times$ loading buffer to yield a $1 \times$ sample and a DNA marker was loaded during each run as a control. The agarose gel was run at $100 \mathrm{~V}$ for approximately $30 \mathrm{~min}$ and then observed under UV for analysis. 


\subsection{UV-C Irradiation Treatment}

UV irradiation treatment of $60 \mathrm{~mm}$ Petri dishes, prepared for sterol extraction following different exposure times: 0, 30, 60, 120, 180, 240, 360 min was performed in a Luzchem (Gloucester, ON, Canada) LZC- $4 \times$ photoreactor ( 4 UV-C lamps, dose of $60,000 \mathrm{~mW} / \mathrm{m}^{2}$ with emission $235-280 \mathrm{~nm}$, and peak emission at $254 \mathrm{~nm}$ ) such that the lamps were above the samples. Prior to the addition in a petri dish, the CHO-K1 cells were cultured, sub-cultured, and then cultured until $90 \%$ confluency at $37^{\circ} \mathrm{C}$ with $5 \% \mathrm{CO}_{2}$ in F-25K culture flasks. Then the cells were added to a petri dish at a concentration of $1 \times 10^{6}$ cells $/ \mathrm{mL}$ with a final volume of $8 \mathrm{~mL}$ of Ham's F-12K supplemented with $10 \%$ FBS media with $1 \%$ penicillin-streptomycin. After each exposure time, the cell viability was analyzed using a $0.4 \%$ solution of Trypan Blue (American BioInnovations, Sparks, MD, USA).

\subsection{Sterol Extraction after UV-C Exposure}

The cell culture remaining after the allotted UV-C exposure time was washed twice with distilled water $\left(\mathrm{dH}_{2} \mathrm{O}\right)$ and centrifuged at $2500 \mathrm{rpm}$ for $10 \mathrm{~min}$. Between each centrifugation, the clear supernatant fluid was discarded and the pellet was resuspended with fresh $\mathrm{dH}_{2} \mathrm{O}$. After the washes were complete, the cell pellet was stored at $-20^{\circ} \mathrm{C}$ overnight and sterols were extracted the following day.

To begin the sterol extraction process, $500 \mu \mathrm{L}$ of $\mathrm{dH}_{2} \mathrm{O}$ and $1 \mathrm{~mL}$ of $10 \% \mathrm{KOH}$ in methanol was added to the cell pellet in a 15-mL centrifuge tube. The $\mathrm{dH}_{2} \mathrm{O} / \mathrm{KOH} /$ cell solution was then transferred to a small glass test tube and $100 \mu \mathrm{L}$ of DMSO and a boiling chip was added. The contents within the test tube were then heated to $90-100{ }^{\circ} \mathrm{C}$ and allowed to boil for about $20 \mathrm{~min}$. This was followed by the addition of $500 \mu \mathrm{L}$ of $\mathrm{dH}_{2} \mathrm{O}$ and then the solution was allowed to cool down to room temperature. This process allows for saponification to occur. The sterols within the cells are released because saponification causes hydrolysis of sterol esters and destroys the cellular tissues.

The free sterols were then extracted with $2 \mathrm{~mL}$ of hexane three times. The sterols travel to the clear organic hexane layer, and the polar compounds, such as phospholipids are attracted to the aqueous layer. Between each hexane addition, the test tubes were vortexed and centrifuged at $3300 \mathrm{rpm}$ for a minute to allow the sterols to reach the organic layer more efficiently. The top organic layer was extracted and transferred to a smaller test tube and dried completely with $\mathrm{N}_{2}(\mathrm{~g})$ at $60{ }^{\circ} \mathrm{C}$.

Once the hexane was completely evaporated, acetone was added to the glass tube to dissolve any residue that might be present. The sample was then vortexed, sonicated to remove sterols from the side of the glass, and dried completely with $\mathrm{N}_{2}(\mathrm{~g})$ at $60^{\circ} \mathrm{C}$. The same process of vortexing, sonicating, and drying with $\mathrm{N}_{2}(\mathrm{~g})$ was performed with methanol two times after the acetone evaporated. Once completely dry, the sterol samples are ready for GC injection after the addition of $20.0 \mu \mathrm{L}$ of methanol. The sterol samples were stored at $-20^{\circ} \mathrm{C}$ for future GC analysis.

\subsection{Gas Chromatography}

A Hewlett Packard 5890 series II model equipped with a flame ionization detector and non-polar capillary column (TG-SQC, $15 \mathrm{~m}$, I.D.: $0.25 \mathrm{~mm}$, Film: $0.25 \mu \mathrm{m}$ ) was used for the GC analysis. The initial temperature was set to $170{ }^{\circ} \mathrm{C}$ for $3 \mathrm{~min}$ and then ramped up at a rate of $20^{\circ} \mathrm{C} / \mathrm{min}$ to a final temperature of $280^{\circ} \mathrm{C}$, followed by an isothermal step for a total time of $30.5 \mathrm{~min}$. The inlet temperature was $245^{\circ} \mathrm{C}$ and the detector temperature was set to $280^{\circ} \mathrm{C}$. Cholesterol was used as a control to demonstrate retention time standards. The sterol profile of the samples isolated after UV exposure was analyzed after injecting $1 \mu \mathrm{L}$ of sample into the GC, then plotting retention time against detector intensity. The peaks in the samples were analyzed using retention time in relation to the standard cholesterol retention time. The concentration of the cholesterol in each sample was calculated by the ratio of the area of the standard cholesterol peak compared to the cholesterol peak area of each sample. 


\section{Conclusions}

Exposure of CHO-K1 cells to $\mathrm{ZnO}$ nanoparticles and UV-C irradiation proved to be damaging in terms of cell viability. UV-visible spectroscopy revealed that the $250 \mu \mathrm{g} / \mathrm{mL}$ of $\mathrm{ZnO}$ dose corresponds to the maximum absorption of $\mathrm{ZnO}$ nanoparticles. Similarities in cell morphology were observed when $\mathrm{CHO}$ cells were exposed to either UV radiation or $\mathrm{ZnO}$ nanoparticles. However, agarose gel electrophoresis performed after treatment demonstrated possible depletion in the ability to produce RNA after the cells were treated with $\mathrm{ZnO}$ concentrations of $25 \mu \mathrm{g} / \mathrm{mL}$ and higher, which suggests that the principal mode of toxic action of $\mathrm{ZnO}$ is through the generation of reactive oxidative species. Gas chromatography traces revealed that CHO-K1 irradiated with UV-C for 0, 60, 240, and $360 \mathrm{~min}$ had dramatic increases in cholesterol concentration present in cellular membranes compared to the wild-type $\mathrm{CHO}$ cells that received no UV treatment. The sharpest increase in cholesterol was observed at $360 \mathrm{~min}$ of exposure, which corresponded to about $20 \%$ cell viability.

Author Contributions: P.B. and T.T.M.N. conceived and designed the experiments; R.E.K. performed the experiments; P.B., R.E.K. and T.T.M.N. analyzed the data and wrote the paper.

Funding: This research was partially funded by the Welch Foundation (V-0004).

Conflicts of Interest: The authors declare no conflict of interest.

\section{References}

1. Shang, L.; Nienhaus, K.; Nienhaus, G.U. Engineered nanoparticles interactiong with cells: Size matters. J. Nanobiotechnol. 2014, 12. [CrossRef] [PubMed]

2. Saha, K.; Agasti, S.S.; Kim, C.; Li, X.N.; Rotello, V.M. Gold nanoparticles in chemical and biological sensing. Chem. Rev. 2012, 112, 2739-2779. [CrossRef] [PubMed]

3. Stratakis, E.; Kymakis, E. Nanoparticle-based plasmonic organic photovoltaic devices. Mater. Today 2013, 16, 133-146. [CrossRef]

4. Saroja, C.; Lakshmi, P.; Bhaskaran, S. Recent trends in vaccine delivery systems, a review. Int. J. Pharm. Investig. 2011, 1, 64-74.

5. Meng, F.H.; Cheng, R.; Deng, C.; Zhong, Z.Y. Intracellular drug release nanosystems. Mater. Today 2012, 15, 436-442. [CrossRef]

6. Yoo, J.W.; Irvine, D.J.; Di2scher, D.E.; Mitragotri, S. Bio-inspired, bioengineered and biomimetic drug delivery carriers. Nat. Rev. Drug Discov. 2011, 10, 521-535. [CrossRef] [PubMed]

7. Sambale, F.; Wagner, S.; Stahl, F.; Khaydarov, R.R.; Scheper, T.; Bahnemann, D. Investigations of the toxic effect of silver nanoparticles on mammalian cell lines. J. Nanopart. 2015, 2015. [CrossRef]

8. Meindl, C.; Kueznik, T.; Bosch, M.; Roblegg, E.; Frohlich, E. Intracellular calcium levels as screening tool for nanoparticle toxicity. J. Appl. Toxicol. 2015, 35, 1150-1159. [CrossRef] [PubMed]

9. Kim, J.S. Toxicity and tissue distribution of magnetic nanoparticles in mice. Toxicol. Sci. 2006, 89, 338-347. [CrossRef] [PubMed]

10. Foley, S.; Crowley, C.; Smaihi, M. Cellular localisation of a water-soluble fullerance derivative. Biochem. Biophys. Res. Commun. 2002, 294, 116-119. [CrossRef]

11. Kashiwada, S. Distribution of nanoparticles in the see-through medaka. Environ. Health Perspect. 2006, 114, 1697-1702. [CrossRef] [PubMed]

12. Zhang, Y.; Nguyen, K.C.; Lefebvre, D.E.; Shwed, P.S.; Crosthwait, J.; Bondy, G.S.; Tayabali, A.F. Critical experimental parameters related to the cytotoxicity of zinc oxide nanoparticles. J. Nanopart. Res. 2014, 16, 2440. [CrossRef] [PubMed]

13. Guo, D.; Bi, H.; Liu, B.; Wu, Q.; Wang, D.; Cui, Y. Reactive oxygen species-induced cytotoxic effects in zinc oxide nanoparticles in rat retinal ganglion cells. Toxicol. In Vitro 2013, 27, 731-738. [CrossRef] [PubMed]

14. Song, W.; Zhang, J.; Guo, J.; Zhang, J.; Ding, F.; Li, L.; Sun, Z. Role of the dissolved zinc ion and reactive oxygen species in cytotoxicity of ZnO nanoparticles. Toxicol. Lett. 2010, 199, 389-397. [CrossRef] [PubMed]

15. Zhang, L.; Fairall, L.; Goult, B.; Calkin, A.C.; Hong, C.; Millard, C.J.; Tontonoz, P.; Schwabe, J.W.R. The IDOL-UBE2D complex mediates sterol-dependent degradation of the LDL receptor. Genes Dev. 2011, 25, 1262-1274. [CrossRef] [PubMed] 
16. Stohs, S.J.; Bagchi, D. Oxidative mechanisms in the toxicity of metal ions. Free Radic. Biol. Med. 1995, 18, 321-336. [CrossRef]

17. Svobodova, A.; Walterova, D.; Vostalova, J. Ultraviolet light induced alteration to the skin. Biomed. Pap. Med. Fac. Univ. Palacky Olomouc Czech Repub. 2006, 150, 25-38. [CrossRef] [PubMed]

18. Hussein, M.R. Ultraviolet radiation and skin cancer: Molecular mechanisms. J. Cutan. Pathol. 2005, 32, 191-205. [CrossRef] [PubMed]

19. Clydesdale, G.J.; Dandie, G.W.; Muller, H.K. Ultraviolet light induced injury: Immunology and inflammatory effects. Immunol. Cell Biol. 2001, 79, 547-568. [CrossRef] [PubMed]

20. Duthie, M.S.; Kimber, I.; Norval, M. The effects of ultraviolet radiation on the human immune system. Br. J. Dermatol. 1999, 140, 995-1009. [CrossRef] [PubMed]

21. Ahmed, F.; Schenk, P.M. UV-C Radiation increases sterol production in the microalga Pavlova lutheri. Phytochemistry 2017, 139, 25-32. [CrossRef] [PubMed]

Sample Availability: Samples of the compounds are not available from the authors.

(C) 2018 by the authors. Licensee MDPI, Basel, Switzerland. This article is an open access article distributed under the terms and conditions of the Creative Commons Attribution (CC BY) license (http://creativecommons.org/licenses/by/4.0/). 